\title{
Hepatitis E vaccines: A mini review
}

\author{
Tauseef Ahmad ${ }^{1,2, * \odot}$, Haroon ${ }^{3}$, Kabir Ahmad ${ }^{4}$, S. Mudasser Shah ${ }^{5}$, Muhammad Waseem Shah ${ }^{6}$, \\ Akbar Hussain ${ }^{7}$, Sajid Jalal ${ }^{8}$, Waqar Ahmad ${ }^{9}$, Muhammad Khan ${ }^{10}$, Harapan Harapan ${ }^{11,12,13}$, Kuldeep Dhama ${ }^{14}$, \\ Mukhtiar Baig ${ }^{15}$, Jin Hui ${ }^{1,2}$
}

${ }^{1}$ Department of Epidemiology and Health Statistics, School of Public Health, Southeast University, Nanjing, China

${ }^{2}$ Key Laboratory of Environmental Medicine Engineering, Ministry of Education, School of Public Health, Southeast University, Nanjing, China

${ }^{3}$ College of Life Science, Northwest University, Xian, China

${ }^{4}$ Liaoning Provincial Key Laboratory of Cerebral Diseases, Department of Physiology, Dalian Medical University, Dalian, China

${ }^{5}$ Department of Psychosomatics and Psychiatry, Zhongda Hospital, School of Medicine, Southeast University, Nanjing, China

${ }^{6}$ Department of Nutrition and Food Hygiene, School of Public Health, Southeast University, Nanjing, China

Correspondence

Tauseef Ahmad, Department of Epidemiology and Health Statistics, School of Public Health, Southeast University, Nanjing, China

Email: hamdard_hu@yahoo.com

History

- Received: Aug 17, 2021

- Accepted: Sep 03, 2021

- Published: Sep 29, 2021

DOI : 10.15419/bmrat.v8i8.690

\section{Check for updates}

\section{Copyright}

(c) Biomedpress. This is an openaccess article distributed under the terms of the Creative Commons Attribution 4.0 International license.

\begin{abstract}
The hepatitis E virus (HEV) is an important public health concern and a significant cause of enterically-transmitted viral hepatitis infections. HEV infection remains a serious threat to life, especially in immunocompromised individuals and pregnant women. Globally, vaccines have had a massive impact on public health and saved millions of lives. Vaccination can reduce the healthcare expenditure, decrease the mortality rate, and increase life expectancy. The availability of commercially effective vaccines is the most effective means for the prevention of HEV. However, the development of classic inactive or attenuated HEV vaccines is not feasible due to the lack of an efficient cell culture system for HEV. In recent years, recombinant HEV vaccine approaches have been explored. Many vaccine candidates have showed potential efficacy against HEV infection. Currently, the only licensed vaccine is Hecolin ", a recombinant vaccine developed by Xiamen Innovax Biotech Co., Ltd. It is available in China. However, there are many hindrances when it comes to the acrossthe-board application of Hecolin and other vaccines worldwide. Large-scale efforts are needed to further evaluate the efficacy and safety of Hecolin in at-risk populations and to pass the World Health Organization prequalification for licensing outside of China.
\end{abstract}

Key words: Hecolin ", Hepatitis E virus, Vaccination, Vaccines

\section{INTRODUCTION}

Hepatitis E infection, caused by the hepatitis E virus (HEV), is the fifth known type of human viral hepatitis and it is considered to be the most common cause of jaundice, acute liver failure, and acute viral hepatitis ${ }^{1-5}$. Despite being an important viral pathogen, HEV and its origin remain involves many unanswered questions ${ }^{6,7}$. The mechanisms of HEV pathogenesis and its replication are poorly understudied, mostly due to the lack of reliable diagnostic methods ${ }^{6,7}$. HEV is common in developing countries, causing small- and large-scale outbreaks. In developed countries, human infections occur mainly through zoonotic transmission ${ }^{8}$.

Although most HEV infections cause mild hepatitis, infection is usually more severe in pregnant women ${ }^{\mathbf{8}}$. Furthermore, HEV infection during pregnancy often leads to premature births, a low birth weight, and infant death ${ }^{9-11}$. In addition, chronic HEV infection has been reported in immunocompromised patients, transplant recipients, and patients receiving chemotherapy ${ }^{12-14}$. According to the World Health Organization (WHO), there are an estimated 20 million HEV infections every year globally. Of these cases, approximately 3.3 million develop into symptomatic cases. In 2015, HEV caused an estimated
44,000 deaths worldwide, accounting for $3.3 \%$ of the mortality due to viral hepatitis ${ }^{15}$.

Vaccines have had an enormous impact on public health around the world, saving millions of lives. Vaccination has the potential to reduce healthcare costs, lower death rates, and extend life expectancy ${ }^{16,17}$. The critical property of vaccines is to stimulate the immune system against diseases. Some vaccines also protect against infection. Since the 1990s, the immunization/vaccination coverage has increased substantially. As a result, millions of lives have been saved. According to the WHO statistics, vaccines save more than 2.5 million deaths per year ${ }^{18,19}$. At present, vaccines are available for more than 30 life-threatening viral and bacterial diseases ${ }^{20,21}$. Vaccinations prevent illnesses and death associated with infectious diseases such as diphtheria, influenza, measles, pneumonia, polio, and pertussis/whooping cough ${ }^{22}$. Several HEV vaccine candidates have progressed into the clinical development stage, and one of them has been approved and licensed only in China ${ }^{23}$.

This review aims to summarize the current development of $\mathrm{HEV}$ vaccines and the key challenges that are a part of vaccine development and deployment. 
${ }^{7}$ School of Basic Health Sciences, Department of Microbiology, Dalian Medical University, Lianing Province, China

${ }^{8}$ Department of Pathophysiology, College of Basic Medical Sciences, Dalian Medical University, Dalian, China

${ }^{9}$ Drug Discovery Research Center, Southwest Medical University, Luzhou, Sichuan, China

${ }^{10}$ Department of Biotechnology and Genetic Engineering, Hazara University Mansehra, Khyber Pakhtunkhwa, Islamic Republic of Pakistan

${ }^{11}$ Medical Research Unit, School of Medicine, Universitas Syiah Kuala, Banda Aceh, Indonesia

${ }^{12}$ Tropical Disease Centre, School of Medicine, Universitas Syiah Kuala, Banda Aceh, Indonesia

${ }^{13}$ Department of Microbiology, School of Medicine, Universitas Syiah Kuala, Banda Aceh, Indonesia

${ }^{14}$ Division of Pathology, ICAR-Indian Veterinary Research Institute, Izatnagar, Bareilly, Uttar Pradesh, India

${ }^{15}$ Department of Clinical Biochemistry, Faculty of Medicine, Rabigh, King Abdulaziz University, Jeddah, Saudi Arabia

\section{TRANSMISSION}

In countries with limited resources, HEV is most frequently transmitted through drinking water contaminated with fecal matter. In Southeast Asia, the number of HEV cases increases during the rainy season ${ }^{24}$. Nevertheless, case numbers have been increasing in the dry season when the drinking water supplies are not flooded or contaminated ${ }^{25}$. Furthermore, the low levels of household sanitation may also increase the risk of HEV infection ${ }^{26}$.

In addition, HEV transmission has been reported via blood and nosocomial routes ${ }^{27,28}$. It is also well documented that a pregnant woman can transmit HEV to her unborn fetus ${ }^{25-29}$. No HEV transmission through sexual intercourse has been documented ${ }^{25-29}$.

\section{HEV TAXONOMY AND GEOGRAPHICAL DISTRIBUTION}

$\mathrm{HEV}$ is a small (27-34 nm) single-stranded positivesense RNA virus from the family Hepeviridae and genus Orthohepevirus (Figure $1 \mathbf{A})^{31,32}$. The virus has a genome of about $7.2 \mathrm{~kb}$ in length with three open reading frames (ORF1, ORF2, and ORF3) (Figure 1 B) $)^{3,31-33}$.

HEV causes infections worldwide but it is more common in low- and middle-income countries with limited access to clean drinking water, acceptable hygiene practices, proper sanitation, and health services. Both sporadic cases and outbreaks have been documented ${ }^{\mathbf{1 5}, 34,35}$. HEV cases are commonly observed to have two different patterns: (i) resource-limited regions with frequent water contamination and (ii) regions with safe drinking water supplies. The HEV infections in developed regions are generally triggered by zoonotic transmission, mainly through undercooked pork products ${ }^{15,36-38}$.

A recent study reported that the seroprevalence of $\mathrm{HEV}$ among countries in Southeast Asia ranged from 2\% (Malaysia) to 77.7\% (Lao People's Democratic Republic) ${ }^{39}$.

Another recent meta-analysis including 1,099,717 subjects from various countries worldwide reported that the HEV IgG and IgM antibody seropositivity was $12.47 \%$ (95\% CI: $10.42-14.67)$ and $1.47 \%$ (95\% CI: $1.14-1.85)$, respectively ${ }^{30}$. The highest HEV IgG seropositivity was reported in Africa, followed by Asia, Europe, North America, South America, and Oceania, as presented in Figure 2. In total, the HEV RNA seropositivity in the general population was $0.20 \%$ (95\% CI: $0.15-0.25)^{30}$. The potential key risk factors for HEV IgG antibody positivity were living in rural areas, exposure to soil, the consumption of raw meat, traveling to high disease burden regions, blood transfusion, contact with dogs, and a low level of education $^{30}$.

\section{HEV VACCINE DEVELOPMENT}

After the discovery of HEV in 1981, attempts have been made to develop effective HEV vaccines ${ }^{\mathbf{4 0 , 4 1}}$. Currently, the advancement of an attenuated or inactivated vaccine is not feasible because HEV cannot be grown reproducibly in cell culture systems. Instead, the development of recombinant protein or nucleic acid-based vaccines has seen significant progress ${ }^{42,43}$.

Meanwhile, human papillomavirus and HEV viruslike particle (VLP) vaccines consist of nanoparticles of 30 and $60 \mathrm{~nm}$ in diameter that contain only the viral capsid protein and no lipids. For HEV VLPs, the central building block is the pORF2 E2 dimer ${ }^{\mathbf{4 4}, 45}$.

At least 11 experimental HEV vaccines have been assessed in non-human primates with a viral challenge ${ }^{46}$. Numerous vaccines have been discovered using a cell culture system for $\mathrm{HEV}^{47,48}$. The results obtained from a study on avian HEV in chickens suggested that oral vaccination using L. lactis expressing a part of the avian HEV-ORF2 protein can counteract hepatitis and liver injury caused by a HEV infection $^{49}$. On the other hand, an alternative cell culture system, the A549 cell line that does not require RNA transfection, was found to support the partial replication of genotype-1 HEV from a patient blood serum sample ${ }^{50}$. The preclinical studies on HEV vaccines are presented in Table 1. The registered clinical trials on HEV vaccines are presented in Table 2. 


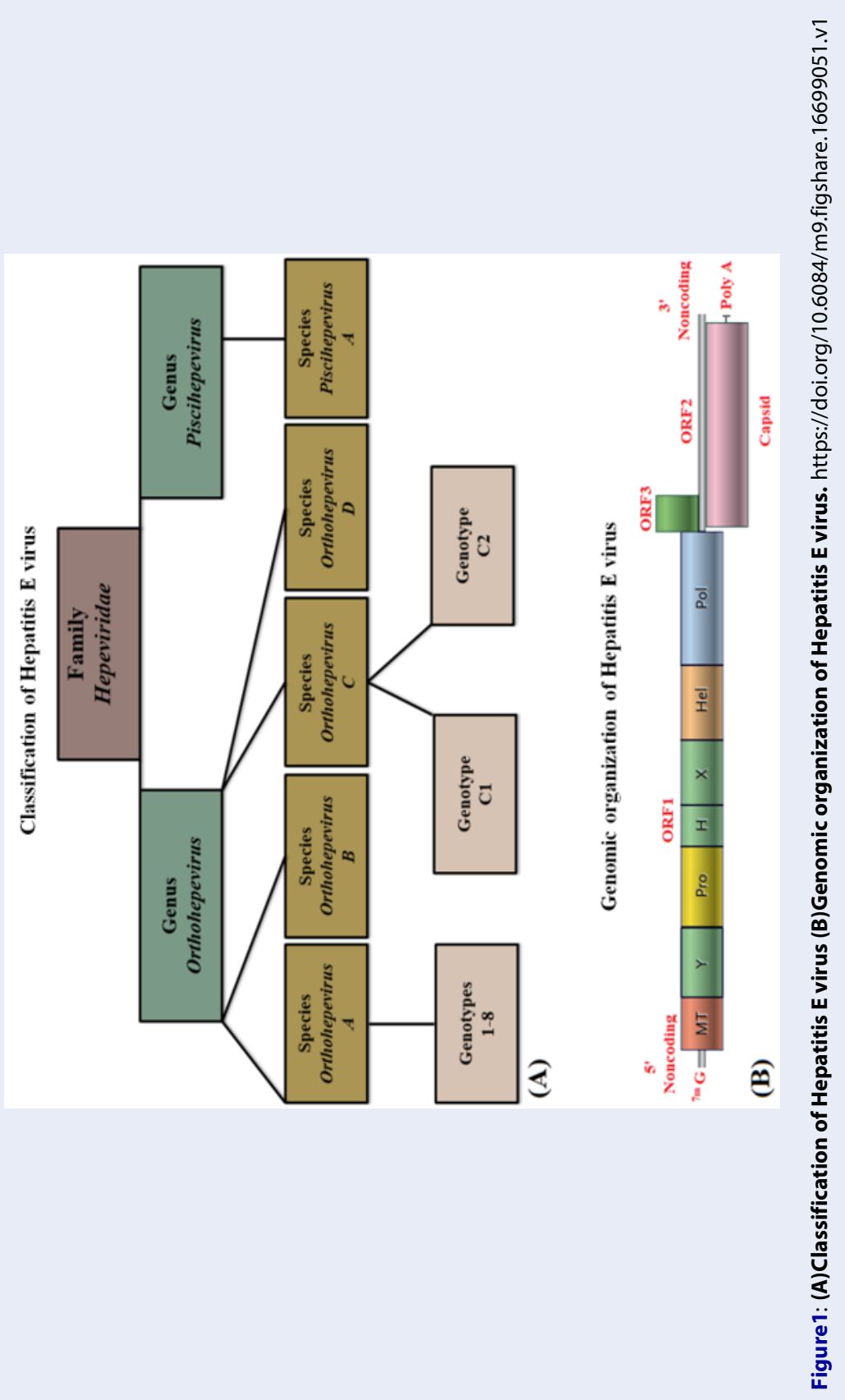


- Anti-HEV IgG antibody prevalence (\%) in different regions

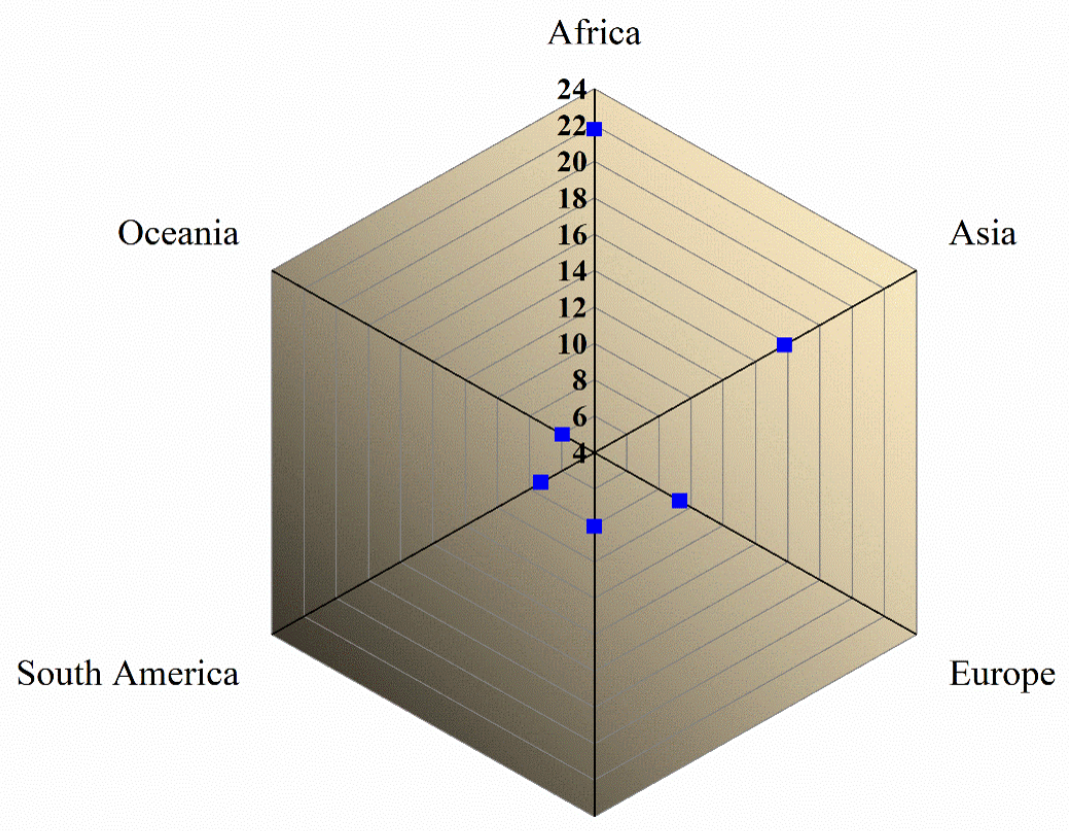

North America

Figure 2: Prevalence (\%) of anti-HEV IgG antibody in differentregions. This Figure is adopted from Li et al. ${ }^{30}$. https://doi.org/10.6084/m9.figshare.16702318.v1

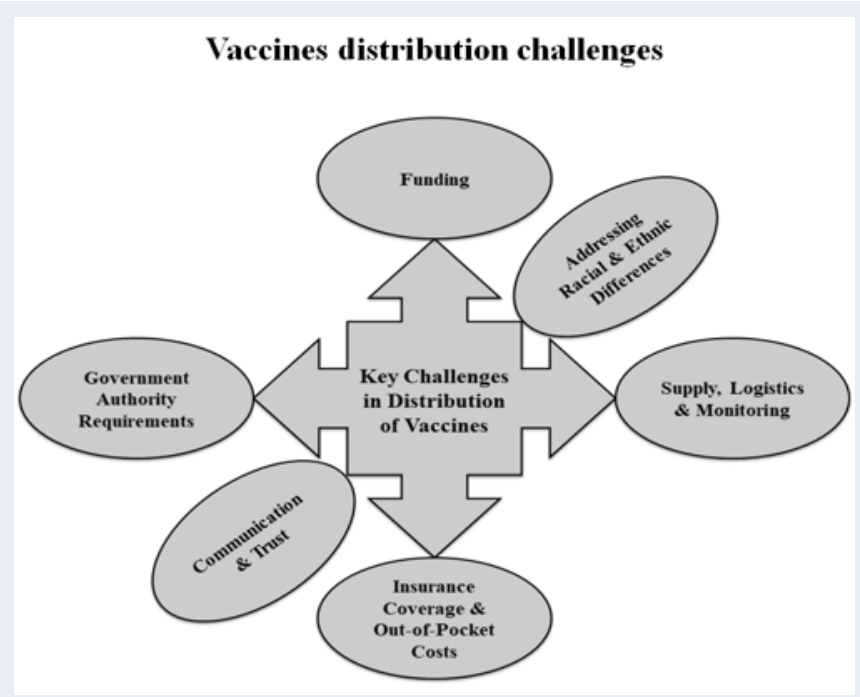

Figure 3: Key challenges in the distribution of vaccines. https://doi.org/10.6084/m9.figshare.16702321.v1 
Table 1: Preclinical studies on HEV vaccines

\begin{tabular}{|c|c|c|c|c|c|c|}
\hline Name & ORF2 range & Stage & Expression & Study country & Subjects studied & References \\
\hline TrpE-C2 & $221-660$ & Preclinical study & Prokaryotes & USA & $\begin{array}{l}\text { Cynomolgus } \\
\text { Macaques }\end{array}$ & Purdy et al. ${ }^{51}$ \\
\hline Bacmid-HEV ORF2 & $126-621$ & Preclinical study & Baculovirus-infected & China & $\begin{array}{l}\text { Sf9 cells, BALB } / \mathrm{c} \\
\text { mice }\end{array}$ & Qi et al. ${ }^{52}$ \\
\hline HP/HEV2.3 & $112-607$ & Preclinical study & Yeast & China & - & Su et al. ${ }^{53}$ \\
\hline HEV ORF2 & $69-600$ & Preclinical study & Yeast & China & $\mathrm{BALB} / \mathrm{c}$ mice & Tong et al. ${ }^{54}$ \\
\hline $\begin{array}{l}\text { HEV truncated } 4(\text { aal- } \\
\text { 111)-ORF2 }\end{array}$ & $112-660$ & Preclinical study & Vectored vaccine & Tunisia, Spain & $\begin{array}{l}\text { Sf9 cells, BHK-21 } \\
\text { cells. mice }\end{array}$ & $\begin{array}{l}\text { Trabelsi et al. }{ }^{55} \text {; } \\
\text { Jiménez et al. }\end{array}$ \\
\hline $\begin{array}{l}\text { tPAsp-PADRE- } \\
\text { truncated ORF2 }\end{array}$ & $112-660$ & Preclinical study & Vectored vaccine & Iran & $\begin{array}{c}\text { CHO \& HEK293 } \\
\text { cells }\end{array}$ & Farshadpour et al. ${ }^{57}$ \\
\hline $\begin{array}{l}\text { Hepatitis A \& E vaccine } \\
\text { (HA+ E vaccine })\end{array}$ & $439-617$ & Preclinical study & $\begin{array}{l}\text { Combined and recombinant chimeric } \\
\text { vaccine }\end{array}$ & China & $180 \mathrm{Balb} / \mathrm{c}$ mice & Dong et al. ${ }^{58}$ \\
\hline HAV-HEp148 & $459-606$ & Preclinical study & $\begin{array}{l}\text { Combined and recombinant chimeric } \\
\text { vaccine }\end{array}$ & $\begin{array}{l}\text { China, } \\
\text { Germany }\end{array}$ & $24 \mathrm{Balb} / \mathrm{c}$ mice & Xiang et al. ${ }^{59}$ \\
\hline HE-ORF2, HA-VP1, & $368-607$ & Preclinical study & $\begin{array}{l}\text { Combined and recombinant chimeric } \\
\text { vaccine }\end{array}$ & China & $40 \mathrm{Balb} / \mathrm{c}$ mice & Gao et al. ${ }^{60}$ \\
\hline HEV-HBsAg & $551-607$ & Preclinical study & $\begin{array}{l}\text { Combined and recombinant chimeric } \\
\text { vaccine }\end{array}$ & China & & Li et al. ${ }^{61}$ \\
\hline GST-NoV P(-)-HEV P & 452-617, & Preclinical study & $\begin{array}{c}\text { Combined and recombinant chimeric } \\
\text { vaccine }\end{array}$ & USA & $\begin{array}{l}\text { HepG2/3A cells, } \\
\text { Balb/c mice }\end{array}$ & Wang et al. ${ }^{62}$ \\
\hline HEV-RV-AstV & $112-607$ & Preclinical study & $\begin{array}{l}\text { Combined and recombinant chimeric } \\
\text { vaccine }\end{array}$ & Iran & sf9 cell & Makvandi et al. ${ }^{63}$ \\
\hline rHEV VLPs & $112-660$ & Preclinical study & Oral immunization $\mathrm{HEV}$ vaccine & Japan, India & $\begin{array}{l}\text { Balb/c mice, } \\
\text { Cynomolgus } \\
\text { monkeys }\end{array}$ & Li et al. ${ }^{6465}$ \\
\hline HEV p179 & $439-617$ & Phase Ib clinical trial & Prokaryotes & China & $\begin{array}{l}\text { Human, mice \& } \\
\text { monkey }\end{array}$ & $\begin{array}{l}\text { Meng et al. }{ }^{66} \text {; Wen et } \\
\text { al. }^{67} \text {;Dong etal. }{ }^{68}\end{array}$ \\
\hline $\begin{array}{l}\text { GSK } \\
\text { vaccine } \\
\text { ORF2(D111/DTM)] }\end{array}$ & $112-607$ & Phase II clinical trial & Baculovirus-infected & $\begin{array}{l}\text { India, USA, } \\
\text { Nepal }\end{array}$ & $\begin{array}{c}\text { Cynomolgus } \\
\text { Macaques, } \\
\text { Human, Sf9 cells }\end{array}$ & $\begin{array}{c}\text { Sehgal et al. }{ }^{69} \text {; } \\
\text { Robinson et al. }{ }^{70} \text {; } \\
\text { Zhang et al. }{ }^{71} \text {; } \\
\text { Shrestha } \text { et al. }{ }^{72}\end{array}$ \\
\hline
\end{tabular}




\section{HEV VACCINE EFFICACY}

Several studies have been conducted to develop HEV vaccines and assess their efficacy, of which only three studies have registered for clinical trials as shown in Table 3. In China, a phase III clinical trial was conducted among participants $(n=112,604)$ aged 16 65 years old. After receiving the complete 3 doses, the Hecolin HEV p239 vaccine showed 100\% (95\% CI, 72-100) efficacy. Additionally, the efficacy was 96\% (95\% CI, 66-99) among the individuals who received at least one dose ${ }^{73}$. The HEV p239 vaccine is immunogenic and well-tolerated. It induces immunity against $\mathrm{HEV}$ infection in the age group older than 65 years ${ }^{74}$. Another study conducted in Bangladesh among pregnant women showed that the HEV p239 vaccination induces immunogenicity against HEV infection and prevented maternal and neonatal deaths due to HEV infection ${ }^{75}$.

In Nepal, another clinical trial (898 in the vaccine group and 896 in the placebo group that received three vaccine doses) of a recombinant HEV protein (rHEV) vaccine showed 95.5\% (95\% CI, 85.6-98.6) efficacy ${ }^{72}$. The intention-to-treat analysis also strengthens the promise of this vaccine. After administering the first dose of the rHEV vaccine, the estimated efficacy was 88.5 to $89.9 \%{ }^{72}$.

The HEV vaccine p179 showed good safety and tolerance after a phase I clinical trial conducted among participants ( $\mathrm{n}=120,16-65$ years) in China. Three different dosages, 20,30 , and $40 \mu$ g of HEV p179 vaccines, were received by the experimental groups with $30 \mu \mathrm{g}$ HEV vaccine 239 Hecolin used as a control. Vaccination occurred at 0-, 1-, and 6-month intervals. The incidence of solicited local adverse reactions (ARs) in the experimental groups was significantly lower than in the control group $(P=0.027)$. However, no significant difference was reported between the incidence of solicited total and systemic ARs in the experimental and control groups. Thus, the tested dosages of the HEV p179 vaccine are well tolerated and safe with no serious adverse reactions ${ }^{76}$.

The use of two truncated ORF2 proteins $(54 \mathrm{KDa}$ and $26 \mathrm{KDa}$ ) as a vaccine showed that they have immunogenicity. It acts as a nanoparticle against HEV infection ${ }^{77}$. A study carried out in China reported that antibody loss is significantly lower for innate immunity compared to immunity acquired from vaccination after 10 years $^{78}$. The recombinant VLP-based Hecolin ${ }^{\circ} \mathrm{HEV}$ vaccine available in China acts as a trivalent vaccine. This vaccine produces an immune response against HEV infection, blocks the activity of novavirus binding to histo-blood group antigens, and inhibits astrovirus infection ${ }^{79,80}$. The Hecolin ${ }^{\circ}$ vaccine completed its phase III clinical trial. It has been licensed in China but is not yet available commercially. Furthermore, to launch the HEV vaccine globally, the safety and efficacy data of HEV p239 is needed for high-risk and immunocompromised groups, including pregnant women and individuals with chronic liver disease, HIV, and immune disorders ${ }^{81-84}$.

\section{KEY CHALLENGES IN VACCINE DISTRIBUTION}

Developing a vaccine is a tremendous challenge, but a considerable challenge will still exist even when one becomes available, specifically getting enough people vaccinated. Misinformation and fear are two of the leading causes of low vaccination coverage. Some of the challenges in the distribution of vaccines are shown in Figure 3. A crucial factor when distributing vaccines is the resource constraints faced by the state or local health departments. Funding issues become severe in developing and undeveloped countries ${ }^{85}$. Providing a complete number of doses according to the need is itself a challenge. Other logistical issues include monitoring, tracking vaccine safety, identifying a broad network of sites for administration, and ensuring that the cold chain requirements are met ${ }^{85}$. Differing rules and regulations across the jurisdictions can also influence the success of vaccine distribution and availability. Covering the vaccine's expenses with insurance enhances the availability of vaccines to individuals. Despite this, limitations remain and some individuals face difficulties accessing the vaccine. Addressing racial and ethnic differences is an unprecedented challenge and has a significant impact on communities. Ensuring the equal and easy availability of a vaccine regardless of any ethnic disparities could improve the success of the vaccine overall. Finally, achieving a high rate of vaccination directly depends on the people's trust in and willingness to receive the vaccine. To some extent, all vaccines must face the public's confidence and this issue must be overcome through robust communication and trustbuilding efforts.

\section{ADVERSE REACTIONS TO VACCINES}

Some common local and systematic reactions such as swelling, pain, irritability, drowsiness, rashes, or fever have been detected after vaccination ${ }^{85}$. Most commonly, erythema at the injection site is reported, but using a longer needle $(25 \mathrm{~mm} v s .16 \mathrm{~mm})$ may decrease the prevalence of injection-site reactions ${ }^{\mathbf{8 5 , 8 6}}$. 
Table 2: Registered clinical trials on HEV vaccine in www.Clinicaltrials.gov.

\begin{tabular}{|c|c|c|c|}
\hline Clinical trial title & Clinical trial No. & Country & Status \\
\hline $\begin{array}{l}\text { A clinical trial to evaluate a recombinant hep- } \\
\text { atitis E vaccine in healthy adults }\end{array}$ & NCT02603055 & China & Completed \\
\hline $\begin{array}{l}\text { A Study on the recombinant hepatitis E vac- } \\
\text { cine (Escherichia coli) (accelerated vaccina- } \\
\text { tion schedule) }\end{array}$ & NCT03168412 & China & Completed \\
\hline $\begin{array}{l}\text { A phase IV clinical trial of the recombinant } \\
\text { hepatitis E vaccine (Escherichia coli) (the lot } \\
\text { consistency trial) }\end{array}$ & NCT03365921 & China & Completed \\
\hline $\begin{array}{l}\text { A phase IV clinical trial of the recombinant } \\
\text { hepatitis E vaccine (Escherichia coli) (the } \\
\text { chronic hepatitis B patients) }\end{array}$ & NCT02964910 & China & Completed \\
\hline $\begin{array}{l}\text { Clinical trial of recombinant hepatitis } \mathrm{E} \text { vac- } \\
\text { cine }\end{array}$ & NCT01014845 & China & Completed \\
\hline $\begin{array}{l}\text { Phase IV clinical trial of recombinant hepati- } \\
\text { tis E vaccine (Hecolin })\end{array}$ & NCT02189603 & China & Completed \\
\hline $\begin{array}{l}\text { Effectiveness trial to evaluate protection of } \\
\text { pregnant women by hepatitis E vaccine in } \\
\text { Bangladesh }\end{array}$ & NCT02759991 & Bangladesh & Completed \\
\hline $\begin{array}{l}\text { A safety and efficacy study of the hepatitis E } \\
\text { vaccine in Nepal }\end{array}$ & NCT00287469 & Nepal & Completed \\
\hline $\begin{array}{l}\text { A phase IV clinical trial of the recombinant } \\
\text { hepatitis E vaccine (Escherichia coli) (Coad- } \\
\text { ministration with recombinant hepatitis B } \\
\text { vaccine) }\end{array}$ & NCT02584543 & China & Completed \\
\hline Safety study of hepatitis E vaccine (HEV239) & NCT03827395 & USA & Completed \\
\hline $\begin{array}{l}\text { Immunogenicity study of the recombinant } \\
\text { human Papillomavirus virus type } 6 / 11 \text { biva- } \\
\text { lent vaccine }\end{array}$ & NCT02710851 & China & Active \\
\hline
\end{tabular}

Table 3: The efficacy of HEV vaccine candidates

\begin{tabular}{|c|c|c|c|c|}
\hline Vaccine & Company & Clinical trials & Efficacy & Reference \\
\hline $\begin{array}{l}\text { HEV vaccine p239 } \\
\text { Hecolin }^{\circ}\end{array}$ & \begin{tabular}{lr} 
Xiamen & \multicolumn{2}{c}{ Innovax } \\
Biotech & Co., Ltd, \\
China &
\end{tabular} & Phase III & $\begin{array}{l}100 \% \text { received all } 3 \\
\text { doses } \\
86.8 \% \text { received at least } \\
\text { one dose }\end{array}$ & Zhu et al. ${ }^{73}$ \\
\hline $\begin{array}{l}\text { Recombinant } \mathrm{HEV} \\
\text { (rHEV) vaccine }\end{array}$ & $\begin{array}{l}\text { GlaxoSmithKline Bi- } \\
\text { ologicals, Rixensart, } \\
\text { Belgium }\end{array}$ & Phase II & $95.5 \%$ efficacy & Shrestha et al. ${ }^{72}$ \\
\hline $\begin{array}{l}\text { Hepatitis E virus } \\
\text { (HEV) p179 }\end{array}$ & $\begin{array}{l}\text { Changchun Institute } \\
\text { of Biological Prod- } \\
\text { ucts Co., Ltd, China }\end{array}$ & Phase I & $\begin{array}{l}\text { Not mentioned. } \\
\text { [Deemed safe and well } \\
\text { tolerated] }\end{array}$ & Cao et al. ${ }^{74}$ \\
\hline
\end{tabular}


Some collaborations have been established to monitor the adverse reactions of vaccines. Vaccine Safety Datalink, a collaboration between the Centers for Disease Control and Prevention and nine health care organizations, was established in 1990 to investigate rare and serious adverse effects of vaccines. The Vaccine Adverse Event Reporting System also monitors vaccine safety for newly approved or recommended vaccines ${ }^{\mathbf{8 7} 88}$. When considering recommended childhood vaccines, many parents are more concerned about the theoretical risks and real effects ${ }^{89}$.

Some vaccines, such as the measles vaccine, are associated with allergic reactions ${ }^{\mathbf{9 0}}$. The varicella vaccine and MMR vaccine are associated with rashes, which appear between 9 to 16 days after vaccination ${ }^{91}$.

\section{CONCLUSIONS}

There is a pressing need for a globally available HEV vaccine. Routine vaccination should be implemented in countries with endemic HEV with a special emphasis on pregnant women and immunocompromised individuals. Improving access to clean drinking water and the sanitary disposal of human waste are the two most critical strategies to prevent HEV infections. Further understanding of the exact HEV burden in endemic areas would assist in developing a vaccination policy if a commercially HEV licensed vaccine becomes available worldwide. However, in most underdeveloped countries where $\mathrm{HEV}$ is a leading cause of acute viral hepatitis, there is a lack of epidemiological data. The endemic countries need to begin monitoring viral hepatitis and stress etiological rather than syndrome diagnosis to benefit from the vaccine optimally.

\section{HIGHLIGHTS}

- Hepatitis E virus (HEV) is an important public health problem in both developed and developing countries.

- Every year, there are an estimated 20 million HEV cases worldwide.

- Currently, the only licensed vaccine, Hecolin", developed by Xiamen Innovax Biotech Co., Ltd, is available in China.

- Large-scale efforts are needed to further evaluate efficacy and safety of Hecolin in risk populations and passing the World Health Organization prequalification and licensing outside China.
- Improved understanding of the exact HEV burden in high endemic areas would assist in developing a vaccination policy if a commercially HEV licensed vaccine is available worldwide.

\section{ABBREVIATIONS}

CDC: Centers for Disease Control and Prevention

FDA: Food and Drug Administration

HEV: Hepatitis E virus

HBGAs: Histo-blood group antigens

HPV: Human papillomavirus

ORF: Open reading frame

rHEV: HEV recombinant protein

VAERS: Vaccine Adverse Event Reporting System

VLPs: Virus-like particles

US: United States

WHO: World Health Organization

\section{ACKNOWLEDGMENTS}

The authors acknowledge their respective universities.

\section{AUTHOR'S CONTRIBUTIONS}

Tauseef Ahmad: Conceptualization, data collection and writing-original draft preparation. All the authors potentially contributed, and approved the final version for publication.

\section{FUNDING}

This review received no financial support from any government or private sector.

\section{AVAILABILITY OF DATA AND MATERIALS}

Not applicable.

\section{ETHICS APPROVAL AND CONSENT TO PARTICIPATE}

Not applicable.

\section{CONSENT FOR PUBLICATION}

Not applicable.

\section{COMPETING INTERESTS}

The authors declare that they have no competing interests. 


\section{REFERENCES}

1. Krawczynski K. Foreword. Hepatitis E virus. Semin Liver Dis. 2013;33(1):1-2. PMID: 23564384. Available from: 10.1055/s0033-1338119.

2. Kamar N, Bendall R, Legrand-Abravanel F, Xia NS, ljaz S, Izopet J. Hepatitis E. Lancet. 2012;379(9835):2477-88. PMID 22549046. Available from: 10.1016/S0140-6736(11)61849-7.

3. Hoofnagle JH, Nelson KE, Purcell RH, Hepatitis E. Hepatitis E. N Engl J Med. 2012;367(13):1237-44. PMID: 23013075. Available from: 10.1056/NEJMra1204512.

4. Chandra NS, Sharma A, Malhotra B, Rai RR. Dynamics of HEV viremia, fecal shedding and its relationship with transaminases and antibody response in patients with sporadic acute hepatitis E. Virol J. 2010;7(1):213. PMID: 20815928. Available from: $10.1186 / 1743-422 \mathrm{X}-7-213$.

5. Purcell RH, Emerson SU. Hepatitis E: an emerging awareness of an old disease. J Hepatol. 2008;48(3):494-503. PMID: 18192058. Available from: 10.1016/j.jhep.2007.12.008.

6. Meng XJ. From barnyard to food table: the omnipresence of hepatitis E virus and risk for zoonotic infection and food safety. Virus Res. 2011;161(1):23-30. PMID: 21316404. Available from: 10.1016/j.virusres.2011.01.016.

7. Guerra JA, Kampa KC, Morsoletto DG, Junior AP, Ivantes CA. Hepatitis E: a literature review. J Clin Transl Hepatol. 2017;5(4):376-83. PMID: 29226104. Available from: 10.14218/ JCTH.2017.00012.

8. Goel A, Aggarwal R, Hepatitis E. Hepatitis E: Epidemiology, Clinical Course, Prevention, and Treatment. Gastroenterol Clin North Am. 2020;49(2):315-30. PMID: 32389365. Available from: 10.1016/j.gtc.2020.01.011.

9. Bergl $\varnothing v$ A, Hallager S, Weis N. Hepatitis E during pregnancy: maternal and foetal case-fatality rates and adverse outcomesA systematic review. J Viral Hepat. 2019;26(11):1240-8. PMID: 31095813. Available from: 10.1111/jvh.13129.

10. Chaudhry SA, Verma N, Koren G. Hepatitis E infection during pregnancy. Can Fam Physician. 2015;61(7):607-8. PMID: 26175368.

11. Berkane $N$, Liere $P$, Oudinet JP, Hertig A, Lefèvre $G$, Pluchino N. From Pregnancy to Preeclampsia: A Key Role for Estrogens. Endocr Rev. 2017;38(2):123-44. PMID: 28323944. Available from: 10.1210/er.2016-1065.

12. Dalton HR, Bendall RP, Keane FE, Tedder RS, ljaz S. Persistent carriage of hepatitis $E$ virus in patients with HIV infection. $N$ Engl J Med. 2009;361(10):1025-7. PMID: 19726781. Available from: 10.1056/NEJMc0903778.

13. Kamar N, Selves J, Mansuy JM, Ouezzani L, Péron JM, Guitard J. Hepatitis E virus and chronic hepatitis in organ-transplant recipients. N Engl J Med. 2008;358(8):811-7. PMID: 18287603. Available from: 10.1056/NEJMoa0706992.

14. Geng Y, Zhang H, Huang W, Harrison TJ, Geng K, Li Z. J Harrison T, Geng K, Li Z, Wang Y. Persistent hepatitis E virus genotype 4 infection in a child with acute lymphoblastic leukemia. Hepat Mon. 2014;14(1):e15618. PMID: 24596581. Available from: 10. 5812/hepatmon.15618.

15. World health Organization (WHO). Hepatitis E. WHO. 2020. Available from: https://www.who.int/news-room/fact-sheets /detail/hepatitis-e (accessed on February 3, 2021). .

16. Andre FE, Booy R, Bock HL, Clemens J, Datta SK, John TJ. Vaccination greatly reduces disease, disability, death and inequity worldwide. Bull World Health Organ. 2008;86(2):140-6. PMID: 18297169. Available from: 10.2471/blt.07.040089.

17. Wang YB, Wang LP, Li P. Perspectives on novel vaccine development. Pol J Vet Sci. 2018;21(3):643-9. PMID: 30468351. Available from: 10.24425/124302.

18. Rappuoli R, Pizza M, Giudice GD, Gregorio ED. Vaccines, new opportunities for a new society. Proc Natl Acad Sci USA. 2014;111(34):12288-93. PMID: 25136130. Available from: 10.1073/pnas.1402981111.

19. Mascola JR, Fauci AS. Novel vaccine technologies for the $21 \mathrm{st}$ century. Nat Rev Immunol. 2020;20(2):87-8. PMID: 31712767.
Available from: 10.1038/s41577-019-0243-3.

20. Nabel GJ. Designing tomorrow's vaccines. N Engl J Med. 2013;368(6):551-60. PMID: 23388006. Available from: 10. 1056/NEJMra1204186.

21. World Health Organization. Immunization. World Health Organization. 2019. Available from: https://www.who.int/ne ws-room/facts-in-pictures/detail/immunization (accessed on September 3, 2021).

22. World Health Organization. Vaccines and immunizations World Health Organization. Available from: https://www.wh o.int/health-topics/vaccines-and-immunization\#tab=tab_1 (accessed on February 3, 2021).

23. Li Y, Huang X, Zhang Z, Li S, Zhang J, Xia N. Prophylactic Hepatitis E Vaccines: Antigenic Analysis and Serological Evaluation. Viruses. 2020;12(1):109. PMID: 31963175. Available from: 10.3390/v12010109.

24. Viswanathan R. A review of the literature on the epidemiology of infectious hepatitis. Indian J Med Res. 1957;45:145-55. PMID: 13438550.

25. Teshale EH, Hu DJ, Hepatitis E. Hepatitis E: epidemiology and prevention. World J Hepatol. 2011;3(12):285-91. PMID: 22216368. Available from: 10.4254/wjh.v3.i12.285.

26. Teshale EH, Grytdal SP, Howard C, Barry V, Kamili S, Drobeniuc J. Evidence of person-to-person transmission of hepatitis $E$ virus during a large outbreak in Northern Uganda. Clin Infect Dis. 2010;50(7):1006-10. PMID: 20178415. Available from: 10. $1086 / 651077$.

27. Arankalle VA, Chobe LP. Hepatitis E virus: can it be transmitted parenterally? J Viral Hepat. 1999;6(2):161-4. PMID: 10607228. Available from: 10.1046/j.1365-2893.1999.00141.x.

28. Robson SC, Adams S, Brink N, Woodruff B, Bradley D. Hospital outbreak of hepatitis E. Lancet. 1992;339(8806):1424-5. PMID 1350840. Available from: 10.1016/0140-6736(92)91250-c.

29. Khuroo MS, Kamili S, Khuroo MS. Clinical course and duration of viremia in vertically transmitted hepatitis $E$ virus (HEV) infection in babies born to HEV-infected mothers. J Viral Hepat. 2009;16(7):519-23. PMID: 19228284. Available from: 10.1111/j.1365-2893.2009.01101.x.

30. Li P, Liu J, Li Y, Su J, Ma Z, Bramer WM. The global epidemiology of hepatitis $E$ virus infection: A systematic review and meta-analysis. Liver Int. 2020;40(7):1516-28. PMID: 32281721. Available from: 10.1111/liv.14468.

31. Pallerla SR, Harms D, Johne R, Todt D, Steinmann E, Schemmerer M. Hepatitis E Virus Infection: Circulation, Molecular Epidemiology, and Impact on Global Health. Pathogens. 2020;9(10):856. PMID: 33092306. Available from: 10.3390/ pathogens 9100856 .

32. Purdy MA, Harrison TJ, Jameel $S$, Meng XJ, Okamoto $H$, der Poel WHV, et al. ICTV Virus Taxonomy Profile: hepeviridae. J Gen Virol. 2017;98(11):2645-6. PMID: 29022866. Available from: 10.1099/jgv.0.000940.

33. Sridhar S, Teng JL, Chiu TH, Lau SK, Woo PC, Hepatitis E. Hepatitis E Virus Genotypes and Evolution: Emergence of Camel Hepatitis E Variants. Int J Mol Sci. 2017;18(4):869. PMID: 28425927. Available from: 10.3390/ijms18040869.

34. Carratalà $A$, Joost $S$. Population density and water balance influence the global occurrence of hepatitis E epidemics. Sci Rep. 2019;9(1):10042. PMID: 31296895. Available from: 10. 1038/s41598-019-46475-3.

35. Melgaço JG, Gardinali NR, de Mello VD, Leal M, Lewis-Ximenez LL, Pinto MA. Hepatitis E: Update on Prevention and Control. BioMed Res Int. 2018;2018:5769201. PMID: 29546064. Available from: 10.1155/2018/5769201.

36. Webb GW, Dalton HR. Hepatitis E: an underestimated emerging threat. Ther Adv Infect Dis. 2019;6:2049936119837162. PMID: 30984394 . Available from: 10.1177/2049936119837162.

37. Osundare FA, Klink P, Majer C, Akanbi OA, Wang B, Faber M Hepatitis E Virus Seroprevalence and Associated Risk Factors in Apparently Healthy Individuals from Osun State, Nigeria. Pathogens. 2020;9(5):392. PMID: 32443767. Available from: 10.3390/pathogens 9050392 . 
38. Aslan AT, Balaban HY. Hepatitis E virus: Epidemiology, diagnosis, clinical manifestations, and treatment. World J Gastroenterol. 2020;26(37):5543-60. PMID: 33071523. Available from: 10.3748/wjg.v26.i37.5543.

39. Raji YE, Toung OP, Taib NM, Sekawi ZB. A systematic review of the epidemiology of Hepatitis E virus infection in South Eastern Asia. Virulence. 2021;12(1):114-29. PMID: 33372843. Available from: 10.1080/21505594.2020.1865716.

40. Emerson SU, Purcell RH. Recombinant vaccines for hepatitis E. Trends Mol Med. 2001;7(10):462-6. PMID: 11597521. Available from: 10.1016/s1471-4914(01)02106-2.

41. Cao Y, Bing Z, Guan S, Zhang Z, Wang X. Development of new hepatitis $E$ vaccines. Hum Vaccin Immunother. 2018;14(9):2254-62. PMID: 29708836. Available from: 10. 1080/21645515.2018.1469591.

42. Qian C, Liu X, Xu Q, Wang Z, Chen J, Li T. Recent Progress on the Versatility of Virus-Like Particles. Vaccines (Basel). 2020;8(1):139. PMID: 32244935. Available from: 10.3390/ vaccines 8010139 .

43. Shouval D. Hepatitis B vaccines. J Hepatol. 2003;39:706. PMID: 14708681. Available from: $10.1016 / \mathrm{s} 0168-8278(03)$ $00152-1$.

44. Li S, Tang X, Seetharaman J, Yang C, Gu Y, Zhang J. Dimerization of hepatitis $E$ virus capsid protein E2s domain is essential for virus-host interaction. PLoS Pathog. 2009;5(8):e1000537. PMID: 19662165. Available from: 10.1371/journal.ppat. 1000537.

45. Zhao Q, Li S, Yu H, Xia N, Modis Y. Virus-like particle-based human vaccines: quality assessment based on structural and functional properties. Trends Biotechnol. 2013;31(11):65463. PMID: 24125746. Available from: 10.1016/j.tibtech.2013. 09.002.

46. Hepatitis E vaccine: WHO position paper, May 2015. Wkly Epidemiol Rec. 2015;90(18):185-200. English, French.

47. Nan Y, Wu C, Zhao Q, Sun Y, Zhang YJ, Zhou EM. Vaccine Development against Zoonotic Hepatitis E Virus: Open Questions and Remaining Challenges. Front Microbiol. 2018;9:266. PMID: 29520257. Available from: 10.3389/fmicb.2018.00266.

48. Shukla P, Nguyen HT, Torian U, Engle RE, Faulk K, Dalton HR. Cross-species infections of cultured cells by hepatitis $E$ virus and discovery of an infectious virus-host recombinant. Proc Natl Acad Sci USA. 2011;108(6):2438-43. PMID: 21262830. Available from: 10.1073/pnas.1018878108.

49. Wang $D$, Zhang $Y$, Ma $C$, Ma D, Zhao Q, Wang F. Live recombinant Lactococcuslactis expressing avian hepatitis virus ORF2 protein: immunoprotection against homologous virus challenge in chickens. Vaccine. 2018;36(8):1108-15. PMID: 29406242. Available from: 10.1016/j.vaccine.2018.01.003.

50. Takahashi M, Tanaka T, Takahashi H, Hoshino Y, Nagashima S, Jirintai. Hepatitis E Virus (HEV) strains in serum samples can replicate efficiently in cultured cells despite the coexistence of HEV antibodies: characterization of HEV virions in blood circulation. J Clin Microbiol. 2010;48(4):1112-25. PMID: 20107086 Available from: 10.1128/JCM.02002-09.

51. Purdy MA, McCaustland KA, Krawczynski K, Spelbring J, Reyes GR, Bradley DW. Preliminary evidence that a trpE-HEV fusion protein protects cynomolgus macaques against challenge with wild-type hepatitis E virus (HEV). J Med Virol. 1993;41(1):90-4. PMID: 8228944. Available from: 10.1002/jmv. 1890410118

52. Qi Y, Fan J, Huang W, Zhao C, Wang Y, Kong FT. Expression and characterization of hepatitis E virus-like particles and nonvirus-like particles from insect cells. Biotechnol Appl Biochem. 2016;63(3):362-70. PMID: 25824972. Available from: 10.1002/ bab.1379.

53. Su CX, Gu MR, Zhang P, Jin ZJ, Meng FH, Chen EJ, et al. Expression of ORF2 protein of HEV genotype IV in Hansenula polymorpha. Sheng Wu Gong Cheng Xue Bao (Chinese). 2007;23(1):73-78. PMID: 17366891.

54. Tong Y, Zhan M, Lu J, Bai Y, Bi S. Immunogenicity of recombinant HEV ORF2 protein expressed in pichia pastoris. Zhonghua Shi Yan He Lin Chuang Bing Du Xue Za Zhi (Chi- nese). 2002;16(1):23-26. PMID: 11986739

55. Trabelsi K, Kamen A, Kallel H. Development of a vectored vaccine against hepatitis E virus. Vaccine. 2014;32:2808-2811. PMID: 24583005. Available from: 10.1016/j.vaccine.2014.02. 041.

56. de Oya NJ, Escribano-Romero $E$, Blázquez $A B$, Lorenzo $M$, Martín-Acebes MA, Blasco R. Characterization of hepatitis $E$ virus recombinant ORF2 proteins expressed by vaccinia viruses. J Virol. 2012;86(15):7880-6. PMID: 22593167. Available from: 10.1128/JVI.00610-12.

57. Farshadpour F, Makvandi M, Taherkhani R. Design, Construction and Cloning of Truncated ORF2 and tPAsp-PADRETruncated ORF2 Gene Cassette From Hepatitis E Virus in the pVAX1 Expression Vector. Jundishapur J Microbiol. 2015;8(12):e26035. PMID: 26865938. Available from: 10.5812/ jjm. 26035.

58. Dong C, Dai X, Meng JH. The first experimental study on a candidate combined vaccine against hepatitis $A$ and hepatitis E. Vaccine. 2007;25(9):1662-8. PMID: 17156900. Available from: 10.1016/j.vaccine.2006.11.001.

59. Xiang K, Kusov Y, Ying G, Yan W, Shan Y, Jinyuan W. A Recombinant HAV Expressing a Neutralization Epitope of HEV Induces Immune Response against HAV and HEV in Mice. Viruses. 2017;9(9):260. PMID: 28914805. Available from: 10.3390/ v9090260.

60. Gao Y, Su Q, Yi Y, Jia Z, Wang H, Lu X. Enhanced mucosal immune responses induced by a combined candidate mucosal vaccine based on Hepatitis A virus and Hepatitis $E$ virus structural proteins linked to tuftsin. PLoS One. 2015;10(4):e0123400. PMID: 25875115. Available from: 10. 1371/journal.pone.0123400.

61. Li HZ, Gang HY, Sun QM, Liu X, Ma YB, Sun MS. Production in Pichia pastoris and characterization of genetic engineered chimeric HBV/HEV virus-like particles. Chin Med Sci J. 2004;19(2):78-83. PMID: 15250239.

62. Wang L, Cao D, Wei C, Meng XJ, Jiang X, Tan M. A dual vaccine candidate against norovirus and hepatitis $E$ virus. Vac cine. 2014;32(4):445-52. PMID: 24291540. Available from: 10.1016/j.vaccine.2013.11.064.

63. Makvandi M, Teimoori A, Neisi N, Samarbafzadeh A. Designing, Construction and Expression of a Recombinant Fusion Protein Comprising the Hepatitis E Virus ORF2 and Rotavirus NSP4 in the Baculovirus Expression System. Jundishapur J Microbiol. 2016;9(11):e40303. PMID: 28138375. Available from: $10.5812 / \mathrm{jjm} .40303$.

64. Li T, Takeda N, Miyamura T. Oral administration of hepatitis $E$ virus-like particles induces a systemic and mucosal immune response in mice. Vaccine. 2001;19:3476-3484. PMID: 11348714. Available from: 10.1016/S0264-410X(01)00059-7.

65. Li TC, Suzaki Y, Ami Y, Dhole TN, Miyamura T, Takeda N. Protection of cynomolgus monkeys against HEV infection by oral administration of recombinant hepatitis E virus-like particles. Vaccine. 2004;22(3-4):370-7. PMID: 14670318. Available from: 10.1016/j.vaccine.2003.08.004.

66. Meng J, Dai X, Chang JC, Lopareva E, Pillot J, Fields HA. Identification and characterization of the neutralization epitope(s) of the hepatitis E virus. Virology. 2001;288(2):203-11. PMID: 11601892. Available from: 10.1006/viro.2001.1093.

67. Wen J, Behloul N, Dai X, Dong C, Liang J, Zhang M, et al. Immunogenicity difference between two hepatitis $E$ vaccines derived from genotype 1 and 4. Antiviral Res. 2016;128:3642. PMID: 26850829. Available from: 10.1016/j.antiviral.2016. 02.002 .

68. Dong C, Meng JH. Expression, purification and immunogenicity of a novel hepatitis E virus-like particle. Xi Bao Yu Fen Zi Mian Yi Xue Za Zhi (Chinese). 2006;22(3):339-342. PMID: 16643795.

69. Sehgal D, Malik PS, Jameel S. Purification and diagnostic utilityof a recombinant hepatitis E virus capsid protein expressed in insect larvae. Protein Expr Purif. 2003;27:27-34. PMID: 12509981. Available from: $10.1016 /$ S1046-5928(02)00574-0. 
70. Robinson RA, Burgess WH, Emerson SU, Leibowitz RS, Sosnovtseva SA, Tsarev S. Structural characterization of recombinant hepatitis $E$ virus ORF2 proteins in baculovirus-infected insect cells. Protein Expr Purif. 1998;12(1):75-84. PMID: 9473460. Available from: 10.1006/prep.1997.0817.

71. Zhang M, Emerson SU, Nguyen H, Engle R, Govindarajan S, Blackwelder WC. Recombinant vaccine against hepatitis $\mathrm{E}$ : duration of protective immunity in rhesus macaques. Vaccine. 2002;20(27-28):3285-91. PMID: 12213398. Available from: 10.1016/S0264-410X(02)00314-6.

72. Shrestha MP, Scott RM, Joshi DM, Mammen MP, Thapa GB, Thapa N. Safety and efficacy of a recombinant hepatitis E vaccine. N Engl J Med. 2007;356(9):895-903. PMID: 17329696. Available from: 10.1056/NEJMoa061847.

73. Zhu FC, Zhang J, Zhang XF, Zhou C, Wang ZZ, Huang SJ. Efficacy and safety of a recombinant hepatitis $E$ vaccine in healthy adults: a large-scale, randomised, double-blind placebocontrolled, phase 3 trial. Lancet. 2010;376(9744):895-902. PMID: 20728932. Available from: 10.1016/S0140-6736(10) 61030-6.

74. Cao YF, Tao H, Hu YM, Shi CB, Wu X, Liang Q. A phase 1 randomized open-label clinical study to evaluate the safety and tolerability of a novel recombinant hepatitis $E$ vaccine. Vaccine. 2017;35(37):5073-80. PMID: 28803715. Available from: 10.1016/j.vaccine.2017.05.072.

75. Xia M, Wei C, Wang L, Cao D, Meng XJ, Jiang X. A trivalent vaccine candidate against hepatitis $E$ virus, norovirus, and astrovirus. Vaccine. 2016;34(7):905-13. PMID: 26778421. Available from: 10.1016/j.vaccine.2015.12.068.

76. Rani D, Saxena R, Nayak B, Srivastava S. Cloning and expression of truncated ORF2 as a vaccine candidate against hepatitis E virus. 3 Biotech. 2018;8(10):414. PMID: 30237961. Available from: 10.1007/s13205-018-1437-2.

77. Kmush BL, Yu H, Huang S, Zhang X, Wu T, Nelson KE, et al. Erratum: Long-term antibody persistence after hepatitis $E$ virus infection and vaccination in Dongtai, China. Open Forum Infect Dis. 2019;6(8):ofz224. PMID: 31390653. Available from: 10.1093/ofid/ofz224.

78. Yu XY, Chen ZP, Wang SY, Pan HR, Wang ZF, Zhang QF. Safety and immunogenicity of hepatitis $E$ vaccine in elderly people older than 65\% UNKNOWN UNICODE CHARACTER 0202F (NARROW NO-BREAK SPACE) years. Vaccine. 2019;37(32):4581-6. PMID: 31262585. Available from: 10. 1016/j.vaccine.2019.04.006

79. Zaman K, Dudman S, Stene-Johansen K, Qadri F, Yunus M, Sandbu S. HEV study protocol : design of a clusterrandomised, blinded trial to assess the safety, immunogenicity and effectiveness of the hepatitis E vaccine HEV 239
(Hecolin) in women of childbearing age in rural Bangladesh. BMJ Open. 2020;10(1):e033702. PMID: 31959609. Available from: 10.1136/bmjopen-2019-033702.

80. Khuroo MS, Khuroo MS. Hepatitis E: an emerging global disease - from discovery towards control and cure. J Viral Hepat. 2016;23(2):68-79. PMID: 26344932. Available from: $10.1111 /$ jvh.12445.

81. Cao Y, Bing Z, Guan S, Zhang Z, Wang X. Development of new hepatitis $E$ vaccines. Hum Vaccin Immunother. 2018;14(9):2254-62. PMID: 29708836. Available from: 10. 1080/21645515.2018.1469591.

82. Walker CM. Adaptive Immune Responses in Hepatitis A Virus and Hepatitis E Virus Infections. Cold Spring Harb Perspect Med. 2019;9(9):a033472. PMID: 29844218. Available from: 10. 1101/cshperspect.a033472.

83. Wu X, Chen P, Lin H, Hao X, Liang Z. Hepatitis E virus: current epidemiology and vaccine. Hum Vaccin Immunother 2016;12(10):2603-10. PMID: 27184971. Available from: 10 1080/21645515.2016.1184806

84. Smith J, Lipsitch M, Almond JW. Vaccine production, distribution, access, and uptake. Lancet. 2011;378(9789):42838. PMID: 21664680. Available from: 10.1016/S0140-6736(11) 60478-9.

85. Centers for Disease Control and Prevention (CDC). Possible side-effects from vaccines. http://www.cdc.gov/vaccines/vac -gen/side-effects.html. Accessed March 10, 2021.

86. Beirne PV, Hennessy S, Cadogan SL, Shiely F, Fitzgerald T, MacLeod F. Needle size for vaccination procedures in children and adolescents. Cochrane Database Syst Rev. 2018;8(8). PMID: 30091147. Available from: 10.1002/14651858. CD010720.pub3.

87. Spencer JP, Pawlowski RHT, Thomas S. Vaccine Adverse Events: Separating Myth from Reality. Am Fam Physician. 2017;95(12):786-94. PMID: 28671426.

88. Health Resources and Services Administration. National vaccine injury compensation program. http://www.hrsa.gov/v accinecompensation/vaccinetable.html. Accessed March 10 2021.

89. Miller L, Reynolds J. Autism and vaccination-the current evidence. J Spec Pediatr Nurs. 2009;14(3):166-72. PMID: 19614825. Available from: 10.1111/j.1744-6155.2009.00194.x.

90. Stratton KR, Howe CJ, Johnston RB. Adverse Events Associated with Childhood Vaccines: Evidence Bearing on Causality. Washington (DC): National Academy Press; 1994.

91. Babl FE, Lewena S, Brown L. Vaccination-related adverse events. Pediatr Emerg Care. 2006;22(7):514-9. PMID: 16871116. Available from: 10.1097/01.pec.0000227874.44878. 40 . 
Ready to submit your manuscript? Choose Biomedpress and benefit from:

- Fast, convenient online submission

- Through peer-review by experienced researchers

- Rapid publication on acceptance

- Free of charge (without publication fees)

Learn more http://www.biomedpress.org/journals/

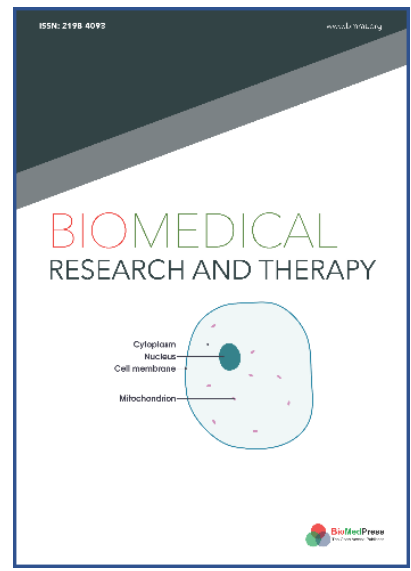

\title{
Biomedical Research and Therapy
}

Indexed: Web of Science (ESCl), Embase, Google Scholar

Journal Citation Indicator (2020): 0.16

Acceptance Rate (2020): 54.32\%

Article Publishing Charge: Free

Submission to first editorial decision: 27 days

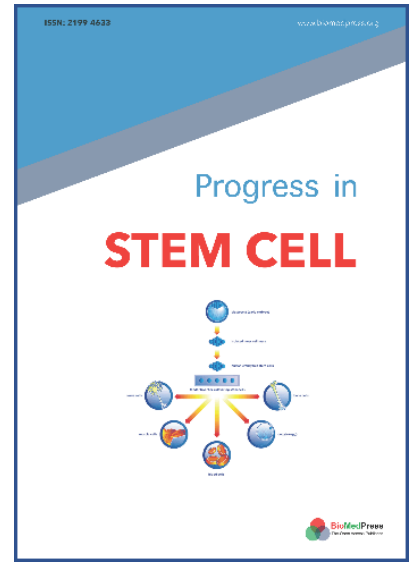

\section{Progress in Stem Cell}

Indexed: Embase, Google Scholar

Acceptance Rate (2020): 78.19\%

Article Publishing Charge: Free

Submission to first editorial decision: 19 days

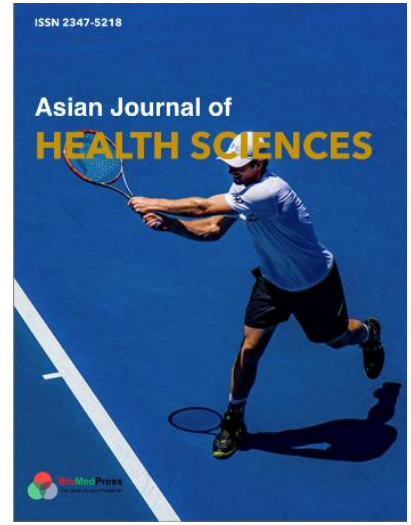

\author{
Asian Journal of Health Sciences \\ Indexed: Google Scholar \\ Acceptance Rate (2020): 72.89\% \\ Article Publishing Charge: Free \\ Submission to first editorial decision: 16.5 days
}

